\title{
Effect of Reverse Logistics on Operational Performance of Sisal Processing Firms in Nakuru County, Kenya
}

\author{
Moses Kabergey, Salome Richu \\ Department of Entrepreneurship Technology Leadership and Management, Jomo Kenyatta University of Agriculture and Technology, Juja, \\ Kenya
}

Email address:

kabergey91@gmail.com (M. Kabergey), salomerichu@yahoo.com (S. Richu)

\section{To cite this article:}

Moses Kabergey, Salome Richu. Effect of Reverse Logistics on Operational Performance of Sisal Processing Firms in Nakuru County, Kenya. International Journal of Economics, Finance and Management Sciences. Vol. 3, No. 5, 2015, pp. 556-565.

doi: $10.11648 /$ j.ijefm. 20150305.27

\begin{abstract}
Sustainability in business is becoming a concept that no serious organization can overlook, especially in supply chain operations. A lot of interest has been built on the concept of sustainability in the recent past because of the mounting pressure from the market, government and international non-governmental bodies especially on sustainable development and environmental protection. To achieve sustainability in the supply chain, organizations currently adopt green supply chain management (GSCM) practices. Reverse logistics is one of the commonly practiced GSCM practice. This study intended to examine the effect of reverse logistics on operational performance of sisal processing firms in Nakuru County. The research adopted correlational research design and was a cross sectional survey. It was guided by two objectives; to establish the effect of product recovery on operational performance of sisal processing firms in Nakuru County and to determine the effect of product reuse on operational performance of sisal processing firms in Nakuru County. The target population for the study was employees working in all sisal processing firms in Nakuru County. Purposive sampling was used to select employees in production, procurement, accounting and finance and marketing departments while stratifies random sampling was used to determine the sample for the study. Data will be collected through a structured questionnaire with 5 points likert scale and analyzed through SPSS version 21. Descriptive statistics was used to describe the aspects of reverse logistics and operational performance. Regression analysis was used to determine the effect of reverse logistics on operational performance. The results were presented using tables accompanied with explanations. The study revealed that product recovery and product reuse both have positive effect on operational performance of sisal processing firms. The researcher recommended that management of processing firms should look at reverse logistics as a strategy to achieve competitive advantage and manage it strategically just like other key management areas. The researcher recommended that study should be conducted on the key determinants and drivers of reverse logistics. Further study should be conducted on the relationship between reverse logistics and social performance of processing/manufacturing organizations. Lastly, further study should be conducted on the role of top management in adoption of reverse logistics practices.
\end{abstract}

Keywords: Reverse Logistic, Operational Performance, Sisal Processing Firms

\section{Introduction}

\subsection{Background}

The issue of sustainable business processes and activities is becoming everyone's business in the current business environment. There is mounting pressure coming from the non-governmental organizations, international environmental bodies and the general public on the issue of sustainability and environmental management. Price Water House Coopers (2008) points out that corporate governance, corporate social responsibility and environmental management have become areas of interest that every organization that needs to compete must consider in their daily operations. They further reveal that these three variables have a clear link with operational performance of an organization.

Internationally, for instance, the International Standards Organization (ISO) has come up with a set of standards and regulations that are applicable globally as far as environmental management is concerned (Hazen et al., 2011). Global Environmental Management Services an organization based in Saudi Arabia has mandated itself to provide technology, 
systems, products and services for waste management (reduction, recovery and recycle), industrial effluent treatment, sewage treatment, odour control, bioremediation and environmental cleanup (Global Environmental Management Services, 2015). IBM has developed strategic framework for the company's environmental management system and environmental affairs objectives. The objectives are aimed at addressing areas such as workplace safety, the conservation of energy and other natural resources, environmental protection, and the development and manufacture of environmentally conscious products (IBM, 2015).

At national level, the governments have also come up with various regulatory measures to ensure business activities are sustainable and all business operations are friendly to the government. In almost every country today, there is an Act of Parliament on environmental management and a body concerned with environment. In Kenya, the National Environmental Management Authority (NEMA) is mandated to ensure the environment is not adversely affected by business activities. At organizational levels, a part from adopting the international and national standards and strategies in ensuring sustainability and environmental conservation, most organizations have developed organizational standards and strategies to take care of such interests (Global Environmental Management Services, 2015).

Because of the much attention given to production and operation costs, sustainability and environmental conservation, organizations adopt initiatives and strategies to ensure costs are reduced to the lowest level possible and productivity is enhanced to the highest level possible. These strategies are adopted in all operations of business. To ensure costs associated with supply chain operations are minimized and productivity sustainability enhanced, organizations resort to sustainable supply chain management practices like green purchasing, green manufacturing, green marketing, and reverse logistics.

Reverse logistics can also be defined as the backward movement of products, components, materials, and equipment and technical systems (Muma et al., 2014). In a production set up, faulty products are normally recalled for rework and surplus materials returned from the production floor. Rogers and Lemboke (1998) defines reverse logistics as 'the process of planning, implementing, and controlling the efficient, cost effective flow of materials (faulty goods, surplus goods, packaging materials and related information) back into the organization from the lower loop of supply chain. Rogers and Tibben-Lembke (1999), cited by Amemba (2013) define reverse logistics as 'the process of planning, implementing, and controlling the efficient, cost-effective flow of raw materials, in-process inventory, finished goods and related information from the point of consumption to the point of origin for the purpose of recapturing value and ensuring proper disposal of wastes and excess materials.

Brito et al. (2002) points out that materials, products, components or even a complete system may sometimes be returned into the supply chain taking a backward movement along the supply chain. Materials that are commonly returned include; manufacturing returns, commercial returns, product recalls, warranty returns, service returns, end of use returns and end of life returns. Products or materials may be returned to the supplier for a number of reasons. Schatteman(2002) discusses the commonly reported reasons that lead to products or materials being returned to the suppliers; customer dissatisfaction with the products, installation and usage problems experienced by the customer, warranty claims, faults in the order processing process, overstocking especially at the retailer's or user's premises, end of product life cycle and manufacture recalls.

Amemba (2013) closely associates reverse logistics with green operations. He further points out that green operation is concerned with product manufacture/remanufacture, usage, handling, logistics and waste management after the product has been designed. Reverse logistics has gained popularity in the recent past due to the perceived benefits attached to it. Such benefits include; enhanced economic performance reduced environmental degradation, improved social performance and improved operational performance. In this study, a close look will be taken at the relationship between reverse logistics and operational performance.

Chaves and Chicarelli (2006) argue that reverse logistics leads to improved operations. According to Lord Kelvin (2010), improved operations ensure; exceptional customer service, public health and safety, fiscal responsibility and community support through appropriate corporate social responsibility processes. Improved operations leads to increase in the amount of goods delivered on time, decrease in inventory levels, decrease in scrap rate, increase in product quality, increase in product line, improved capacity utilization (Ninlawan et al., 2010). In addition, it leads to reduced labor cost, increased productivity increased visibility of associate performance, increased facility throughput and improved service levels (Spiers, 2010). This study intends to look at the relationship between reverse logistics and operational performance in sisal processing firms in Nakuru County.

\subsection{Problem Statement}

Reverse logistics as a supply chain concept emerged alongside other green supply chain management practices in an attempt to enhance sustainability in organizational operations (Green et al., 2012). Since its emergence, scholars have conducted studies to relate reverse logistics with various components of supply chain management like supply chain performance and supply chain efficiency (Muma et al, 2014). Studies have also related reverse logistics with aspects of organizational performance such as; environmental performance, social performance and economic performance. Most of these studies have been conducted in western and eastern part of the world like US and China. For instance, Turrisi (2012) looked studied the impact of reverse logistics on supply chain performance in Italy while Khor and Udin (2012) conducted a study on impact of reverse logistics product towards business performance in Malaysian E\&E Companies. In Kenya, very few studies have been conducted to relate reverse logistics with operational performance. These studies 
had concentrated on the manufacturing firms and the electronic industry (Muttimos, 2014) with no such study being conducted among the sisal processing firms. There was therefore no clear evidence as to whether sisal processing firms can achieve improved operational performance through adoption of reverse logistics practices. It was therefore evident that there existed knowledge gap that needs to be filled through research. This study sought to help bridge this gap by determining the effect of reverse logistics on operational performance of sisal processing firms in Nakuru County.

\subsection{Research Objectives}

i. To establish the effect of product recovery on operational performance of sisal processing firms in Nakuru County.

ii. To determine the effect of product reuse on operational performance of sisal processing firms in Nakuru County.

\subsection{Research Hypothesis}

Ho1: Product Recovery does not have significant effect on operational performance of sisal processing firms in Nakuru County.

Ho2: Product Reuse does not have significant effect on operational performance of sisal processing firms in Nakuru County.

\subsection{Conceptual Framework}

The study was guided by the framework presented in figure 1 .

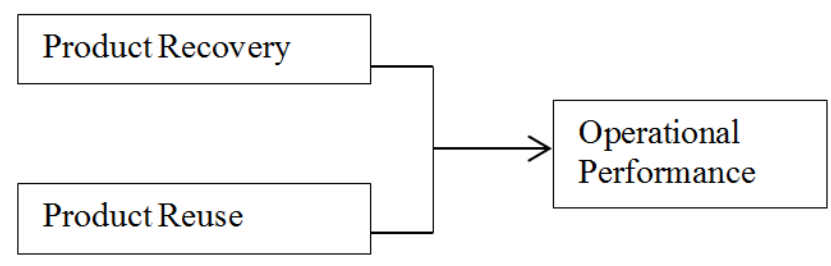

Figure 1. Conceptual Framework.

\section{Literature Review}

\subsection{Theoretical Review}

The study was guided by Institutional Theory. Institutional theory is one of the most popular theories that have been used to understand how organizations assimilate and develop operational strategies (Laosirihongthong, 2013). According to institutional theory, organizational strategies can only be successfully implemented if the strategies are implemented in a participatory manner. Organizations are formal institutions that have structures. These organizations have stakeholders that have varied interests. As such it is important to have regulations, routines, norms and conventions that guide organizational practices. A desirable organizational culture can be developed through inculcation of certain organizational behavioral system in individuals (Amenta Ramsey, 2010). Cultural and institutional forces affect the development of institutional models (Mayer, 2007).Strategies like sustainable supply chain management practices must be implemented through well-developed models and a collaborative and participative approach. Actually, the strategy does not only need participation of internal players but also stakeholders in the external supply chain management.

Issues of environmental management are characterized with increased pressure from the government, NGOs and the general community. As such, organizational strategies relating to environment such as reverse logistics require consideration of stakeholders' interests. Laosirihongthong (2013) points out that several studies that have been carried out in developed countries show that organizations driven by institutional norms and culture are better placed in enhancing their competitive advantage through adoption of environmental conservation practices. This is because the organizations are more likely to take into considerations external and internal stakeholders' interests thereby enhancing acceptance of ownership of such strategies across the organization.

\subsection{Reverse Logistics}

The products that have already joined the supply chain may also be channeled back on grounds of being defective or of poor quality. In practical business environment, products that majorly reverse their course in the supply chain are; manufacturing returns, commercial returns, recalled products, warranty returns, service returns, end-ofuse returns and end-of-life returns (Price Water House Coopers, 2008). These products are returned due to reasons such as; poor packaging and quality issues (Brito, et al., 2002). According to Schatteman (2010), products are returned because of the following reasons; unsatisfactory quality, installation or usage problems, warranty claims, faulty order processing, retail overstock, end of product life cycle or product replacement and manufacture recall. As Price Water House Coopers (2008) points out, returned products often go through a recovery process. The process involves; product/materials acquisition, products/materials collection, product sorting, testing, products recovery and depending on the final state, product redistribution and sales or disposal. According to Chaves and Chicarelli (2006), reverse logistics activities can be presented diagrammatically as shown in figure 2.1 .

European Working Group (2004) cited by Price Water House Coopers (2008) defines reverse logistics as "The process of planning, implementing, and controlling flows of raw materials, in-process inventory, and finished goods, from a manufacturing, distribution or use point to a point of recovery or point of proper disposal". According to Amemba et al. (2013), reverse logistics networks relate to coordination of requirements, supply uncertainty, returns disposition, postponement and speculation. Brito, et al. (2002) observe that reverse logistics activities involve collection of recovered products and redistribution of processed goods. Amemba et al. (2013) further point out that the reverse logistics activities should be responsive to the environment.

When products are manufactured, they are channeled into 
the supply chain so as to reach the final consumers. However, in practical business environment, not all products reach the final consumers. Along the supply chain, materials may take the reverse course through a recovery process. There are therefore two loops in their entire lives. The open loop supply chain and closed loop supply chain (Brito, et al., 2002). Figure 2 shows the supply chain loops and customer return reasons.

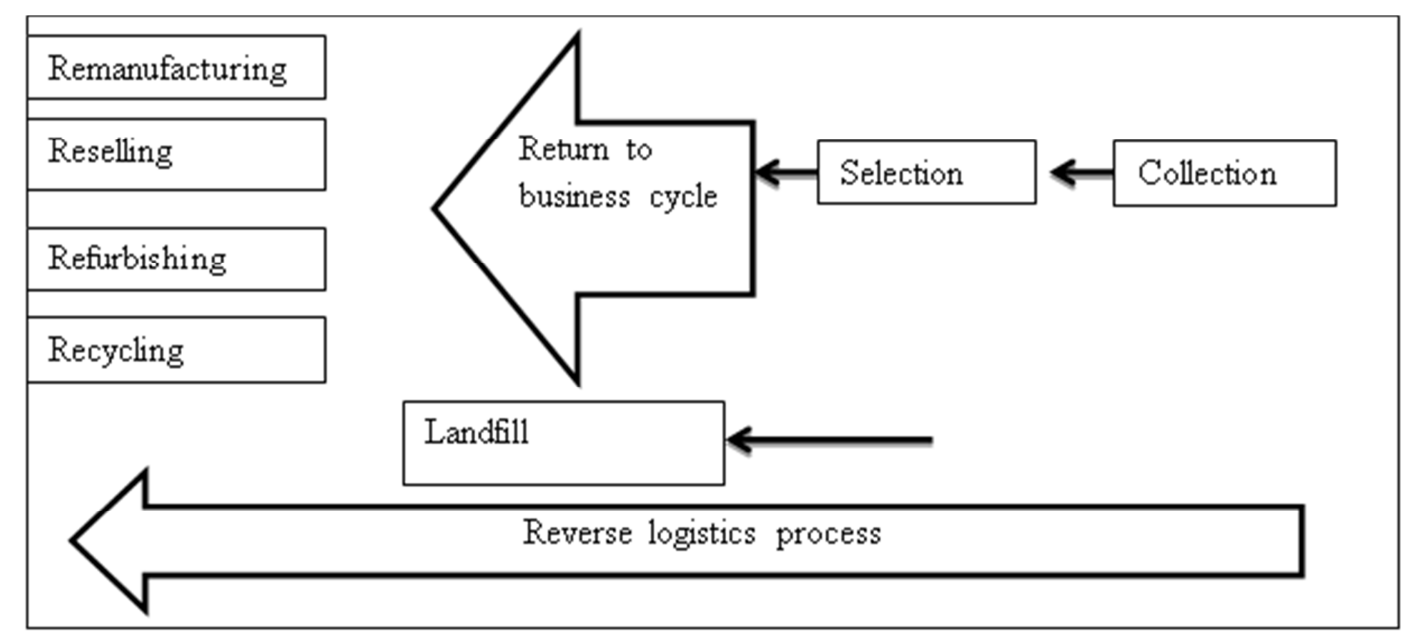

Source: Chaves and Chicarelli (2006)

Figure 2. Activities of Reverse Logistics.

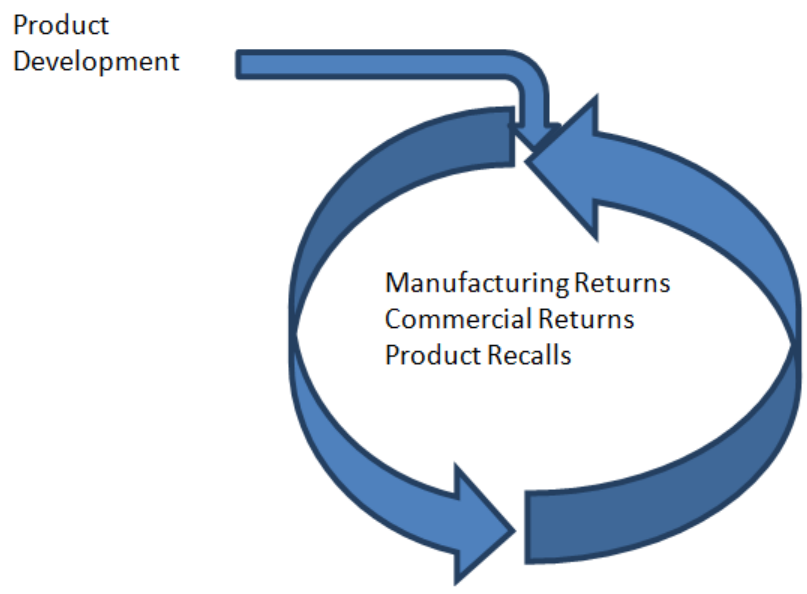

Upper Supply Chain Loop

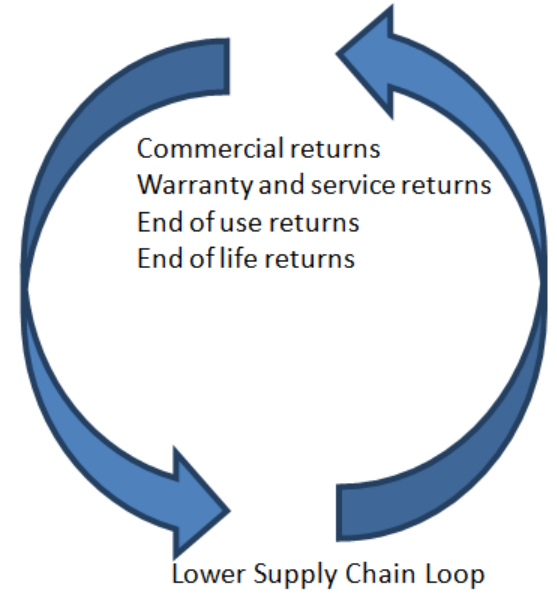

Lower Supply Chain Loop

Figure 3. The Product Life-path and Return Reasons.

Source: Brito, et al. (2002) Reverse logistics accounts for significant portion of logistics cost. For instance, in the US, reverse logistics accounts for 10.7 percent of the total logistics cost and is approximately a half of the US's gross domestic product. Hazen et al. (2001) identified three practices of reverse logistics; reuse, remanufacture and recycle. Reuse is where the customers return unused product back to the seller, normally the retailer. When this happens, the products are reintroduced into the supply chain. Reuse also includes return of reusable packaging materials. When products are returned to retailers, the products return to the organization through reverse logistics. Remanufacture on the other hand involves repair, refurbishing and overhauling an item to revive the original product. Normally, only products are not in their usable state or are beyond repair are remanufactured. Organizations with properly managed supply chain activities can use remanufacturing to enhance their economic performance since they are able to create value in products that had already lost value. It brings back life in a dead product. Recycle is the third component of reverse logistics and involves recovering all returned materials and products to reintroduce value into the products.

Zheng and Zhang (2010) on the other hand conceptualize reverse logistics in terms of recycling and waste management; collection, classification, processing, packaging, handling, storage, and distribution to specialized treatment facility for processing repair of faulty and failed products, return of packaging materials. Rogers and TibbenLembke (1998) observes that reverse logistics is majorly on two materials; products and packaging. Reverse logistics activities that relate to materials include return to suppliers, resell, sell via outlet, salvage, reconditioning, refurbishing, 
remanufacturing, materials reclaiming and recycling. On the other hand, packaging activities include reuse, refurbishing, materials reclaiming and salvaging. The products and materials managed through these activities result from supply chain partners and the end users.

\subsubsection{Product Recovery}

Product recovery is considered as a way of achieving sustainability in business achieving economic benefits. Lindahl (2002) considers products recovery as the process of reuse and recycling. Products recovery is aimed at retrieving the products value when a product ceases to fulfill the desired value. Gungor and Gupta (1999) define products recovery as a combination of remanufacture, reuse and recycling. They further point out that materials recovery is done to recover the economic value in materials and enhance solid waste management, to respond to market requirement and to comply with government regulations.

According to Thierry et al. (1995), the main objective of recovery is to regain as much as possible the economic and ecological value of the products and materials. It enables the organization recover value that would otherwise be lost. A part from products and materials, wastes can also be recovered to enhance environmental responsiveness and performance. According to Fleischmann, et al. (2001), apart from the benefits, other drivers to recovery include; increased environmental concern among customers, the government and the general public, legislation, international standards and best practices.

\subsubsection{Product Reuse}

According to Amemba (2013), reuse strategy is one of strategies of waste management that is believed to be most environmentally friendly. Hazen et al. (2011) defines reuse as the process of recovering any piece of returned product that may have some value. Reuse of materials occurs in cases where the customers return unused products to the point of purchase thereby returning the product back into the supply chain. Reuse of materials may also occur through reutilization of packaging or shipping materials. According to Hazen et al. (2011) customers return products that are either completely unused or that are partly used. For partly used products to be reused, the products should be in a position to be used without any upgrade or modification. Products that are not in the usable state must be channeled back to the manufacturers through reverse logistics either for repair or re-development.

Reuse of materials and products is associated with a number of benefits to organizations that adopt it. According to Reuse Development Organization (2014), there are three main benefits of reuse of materials and products. The first benefit is environmental benefits. Reuse of materials provides environmentally preferred alternatives to waste management and disposal of excess and obsolete materials. The second set of benefits is community benefits. Reuse of materials and products leads to improved social environment that improves social welfare of product users and society in general. The last sets of benefit are the economic benefits. Reuse allows recovery of value that could otherwise be lost as well as reduce casts of acquiring products and operating the business.

\subsection{Operational Performance}

According to Green et al. (2012), operational performance is associated with production capabilities of the organization's production plant to produce and deliver products to customers while to Zhu et al. (2008), operational performance relates to organization's capabilities to more efficiently produce and deliver products and services that satisfy their customers.

Ninlawan et al. (2010) points out that improved operations leads to increase in the amount of goods delivered on time, decrease in inventory levels, decrease in scrap rate, increase in product quality, increase in product line, improved capacity utilization. Operational performance is associated with the following benefits; reduced labor cost, increased productivity, increased visibility of associate performance, increased facility throughput, extending capacity and improved service levels (Spiers, 2010), reduced customer service complaints, reduced technical quality complaints and planned maintenance (Failte Ireland, 2013).

Spiers, (2010) discusses four indicators of operational performance. The first indicator is operations improvement which looks at the best practices of the organizational operations and the extent to which they achieve efficiency and effectiveness in such operations. The second indicator is productivity tracking which looks at departmental and organizational wide tracking to allow effective management of operations and give timely feedback on performance. The third indicator is the engineered standards developed through time and motion studies to measure individual standards. Engineered standards must be objective and must provide accurate and fair goals. The last indicator is incentive program that looks at how performance is rewarded.

There are four keys to operational performance. The first key is operations improvement aimed at simplifying and standardizing distribution and manufacturing. Operations procedure must be understood by the stakeholders and all stakeholders empowered to perform the various functions. The second factor is productivity tracking. It is important to track departmental and facility wide productivity and costs. Accurate productivity is associated with benefits such as balanced staffing and best allocation of resources. The third key factor is engineered standards. Standards must be developed through time and motion studies and aimed at measuring individual objectives and goals. The last key aspect is performance incentive program that is aimed at rewarding performance. Naturally, employees need to be motivated and their contribution to the organization recognized. These four key aspects have direct benefits to the organization such as; reduced labor cost through increased productivity, increased visibility of associate performance, increased facility throughput, extending capacity, increased associate retention and morale, improved management skills and effectiveness, development of self-directed work force through metrics and accountability and improved service to customers. According to Laosirihongthong (2013), the 
indicators of improved operational performance include; Improved compliance to government and international regulations, improved environmental performance, reduced energy consumption and reduced material usage. In Addition, Muma et al. (2014) associates operational performance with improved profitability, reduced production cost, reduced procurement costs, and enhance intangible performance.

\subsection{Empirical Review}

Price Water House Coopers (2008) conducted a research on how to achieve an agile and efficient reverse chain within the consumer electronics industry. In their report, they pointed out that reverse logistics is not one party's affair. They also established that reverse logistics operations are critical functions of supply chain and therefore need to be properly managed. The report proposed five points' recommendations that may be adopted by any organization in its reverse logistics. The first recommendation is that the process must start with analysis of the current situation in the reverse chain. This enables the organization to prioritize, eliminate unnecessary costs and maximize returns. The second recommendation is that there must be awareness a cross the organization that a customer centered approach of management does not only create value but also maintain value in the organization. This will organization's perception and approach of managing reverse supply chain operations. The next recommendation is that reverse logistics operations must be optimized from an operations perspective so as to maximize value to the organization. The forth recommendation is that the reverse logistics operations must be aligned with customer requirements. It must therefore take a multidimensional approach considering organizational structure, systems, structure and people. Lastly, management of reverse operations must be a collaborative affair where every player has clearly outline roles.

Greve and Davis (2010) conducted a study on how to recover lost profit through reverse logistics. In their study, they recommended the following strategies for an effective reverse logistics system; the first recommendation is that the organization must first know its returns. Secondly, the organization must attach value to the returns. The organization must be in apposition to restore value to its customers. Thirdly, it is important to assess the organizations infrastructure. This will determine the organizations ability to recover products and restore their value. Fourthly, it is important to identify success areas depending on the opportunities and benefits an organization associate with recovered products. Lastly, the organization must commit to success by developing an internal process and capacity as well as build an organizational culture that embraces such strategies.

Reverse logistics has direct relationship with value addition. This is because of the following reasons; reverse logistics improves customer service, reverse logistics directly improves quality management, reverse logistics leads to enhanced value creation from recovered materials which would otherwise be wasted and lastly, reverse logistics enhances revenue collection since a tax system can be integrated with the reverse logistics operations. Chaves and Chicarelli (2006) conducted a study titled; reverse logistics and the relation reverse logistics and the relation between industry and retail industry and retail in the after in the aftersale reverse flow management. The study revealed that most retailers look at performance of their suppliers in terms of availability, operational performance and reliability. The study also established that reverse logistics needs certain factors in order to be efficient. These factors include; Good entrance controls, mapped and formalized processes, reduced time cycle, accurate information systems, planned logistics network and cooperative relations in the supply chain.

A study conducted by (Hazen 2011) on diffusion of green supply chain management examined perceived quality of reverse logistics and revealed that while organizations adopt reverse logistics practices to recapture lost value and ensure customer service, customers consider remanufactured and recycled products as of lower quality. Customers tend to think that newly manufactured products are of better quality. Many organizations that adopt reverse logistics do not only adopt these practices to recover lost value but also to achieve competitive advantage through enhance quality achieved through the reverse logistics activities. However, the reality in the market shows that the perception of product users is the opposite of the reality.

Laosirihongthong (2013) and Muma et al. (2014) conducted studies to determine the relationship between green supply chain management and organizational performance. The findings of both studies revealed that legislation and regulation is key in implementation of environmentally friendly supply chain management practices such as reverse logistics. The study revealed that the level of adoption of reverse logistics is still unpopular among many manufacturing organizations. Factors blamed for the low level of adoption include; prohibitive costs associated with development reverse logistics system, the belief that reverse logistics is an impractical concept that cannot be implemented in the current market environment given the level of development of supply chain infrastructure. Another factor that leads to reduced adoption of reverse logistics practices is lack of clear understanding of the economic value of reverse logistics practices.

Shumon et al. (2010) conducted a study titled 'Prospects of remanufacturing: a Bangladesh perspective' the study revealed that remanufacturing is viewed by many organizations as nuisance which prevents them from recognizing the benefits of remanufacturing. The findings further revealed that remanufacturing is associated with benefits consumers such as; an opportunity to acquire high quality products at relatively lower price. The study also revealed that remanufacturing leads to improved environmental management.

\section{Research Methodology}

This study adopted a correlational research design. Correlational research design describes the relationship 
between two or more variables or predicts a variable from another variable (Oso and Onen, 2011). It was a cross sectional survey as primary data was collected from selected members of the population at one point. The population elements in this study were the employees working in all departments of the sisal processing firms in Nakuru County while the sample frame for this study included the permanent employees working in all departments in Athinai Sisal Estate and Lomolo (1962). The researcher adopted purposive sampling to select permanent employees working in Athinai Sisal Estate and Lomolo (1962) Ltd who were in procurement, production, marketing, accounting and finance departments. Since the sample frame constituted sub groups (strata), the researcher adopted stratified random sampling to ensure all sub groups are adequately presented in the study. A sample of 85 respondents was arrived at.

Structured questionnaires were used to collect primary data. Questionnaires were developed with research items on the research variables. The questionnaires were used to collect research data. Since data collected was qualitative in nature, a five point likert scale was used. Questionnaires were preferred since they are easy to analyze and save time in data collection (Oso and Onen, 2011). The questionnaires were self-administered by the researcher through drop and pick techniques. Before data was collected, the researcher obtained authorization letter from the university that was used to gain access to the sisal firms.

To test the validity and reliability of the research instruments, a pilot test was conducted in Majani Mingi Sisal Estate Ltd. This firm was excluded in the actual study. According to Mugenda and Mugenda (2003), the number involved in the pilot test should not be large. A pretest sample of between $1 \%$ and $10 \%$ is good depending on the sample size. In this study, a total of 10 questionnaires were distributed and collected afterwards for analysis. The questionnaires were coded in SPSS version 21 and Crocbach was computed and compared with the threshold value of 0.7 . an overall value of 0.755 was obtained which implied that the research instruments were reliable.

This researcher used both descriptive and inferential analysis. Frequencies and percentages were used to analyze background data on employees, mean and standard deviation were used to describe aspects of reverse logistics and operational performance while correlation analysis was used to determine the relationship between the independent variable (reverse logistics) and dependent variable (operational performance). Regression analysis was then used to test the effect of reverse logistics on operational performance. The findings of this study were presented using tables. Every table were be accompanied by result interpretation. The study was guided by the following multiple regression model;

$$
\mathrm{Y}=\beta_{0}+\beta_{1} \mathrm{X}_{1}+\beta_{2} \mathrm{X}_{2}+\varepsilon
$$

Where; Y - Operational Performance

$\beta_{0}$ - Constant

$\beta_{1}$ to $\beta_{3}$ - Regression coefficients

$$
\begin{aligned}
& X_{1} \text { - Recovery } \\
& X_{2} \text { - Reuse } \\
& \varepsilon \text { - Error term }
\end{aligned}
$$

\section{Research Findings, Conclusions and Recommendations}

\subsection{Findings on Product Recovery}

The findings on product recovery were as presented in table 4.1 .

Table 4.1. Response on Product Recovery.

\begin{tabular}{llllll}
\hline Statement & N & Min & Max & Mean & Std. Dev. \\
\hline $\begin{array}{l}\text { Firm has system to recover } \\
\text { faulty products }\end{array}$ & 68 & 1 & 4 & 3.40 & .813 \\
$\begin{array}{l}\text { Firm has system to recover } \\
\text { excess products }\end{array}$ & 68 & 1 & 5 & 3.53 & .722 \\
$\begin{array}{l}\text { Firm recovers waste materials } \\
\text { and used up materials }\end{array}$ & 68 & 1 & 5 & 3.65 & .860 \\
$\begin{array}{l}\text { Firm has system to return } \\
\text { faulty materials to suppliers }\end{array}$ & 68 & 1 & 5 & 3.69 & .738 \\
$\begin{array}{l}\text { Firm encourages distributors } \\
\text { and consumers to return faulty } \\
\text { products }\end{array}$ & 68 & 2 & 5 & 3.81 & .718 \\
$\begin{array}{l}\text { Firm recovers materials that are } \\
\text { harmful to environment }\end{array}$ & 68 & 1 & 5 & 3.31 & 1.011 \\
$\begin{array}{l}\text { Firm recovers packaging } \\
\text { materials }\end{array}$ & 68 & 1 & 5 & 3.01 & .889 \\
\begin{tabular}{l} 
Valid N (list wise) \\
\hline
\end{tabular} & 68 & & & & \\
\hline
\end{tabular}

\subsection{Findings on Product Reuse}

\begin{tabular}{|c|c|c|c|c|c|}
\hline Statement & $\mathbf{N}$ & Min & Max & Mean & $\begin{array}{l}\text { Std. } \\
\text { Dev. }\end{array}$ \\
\hline $\begin{array}{l}\text { Firm reuses packaging materials } \\
\text { where possible }\end{array}$ & 68 & 1 & 5 & 3.35 & .943 \\
\hline $\begin{array}{l}\text { Firm uses packaging materials that } \\
\text { can be reused for other purposes }\end{array}$ & 68 & 1 & 5 & 3.40 & .849 \\
\hline $\begin{array}{l}\text { Firm trains employees on reuse and } \\
\text { recycling as waste management } \\
\text { strategies }\end{array}$ & 68 & 1 & 5 & 3.60 & .866 \\
\hline $\begin{array}{l}\text { Firm has written down policies that } \\
\text { relate to reuse }\end{array}$ & 68 & 1 & 5 & 3.59 & .902 \\
\hline $\begin{array}{l}\text { Firm purchases recycled products } \\
\text { when on offer in the market as } \\
\text { opposed to new products }\end{array}$ & 68 & 1 & 5 & 3.63 & .945 \\
\hline $\begin{array}{l}\text { Firm encourages distributors and } \\
\text { customers to return used products } \\
\text { for reuse }\end{array}$ & 68 & 1 & 5 & 3.34 & .940 \\
\hline $\begin{array}{l}\text { Firm instruct customers to reuse } \\
\text { packaging materials and products } \\
\text { where possible }\end{array}$ & 68 & 1 & 5 & 3.43 & 1.083 \\
\hline Valid N (list wise) & 68 & & & & \\
\hline
\end{tabular}

The findings on product reuse were as presented on table 4.2.

Table 4.2. Response on Reuse. 


\subsection{Findings on Operational Performance}

Research findings on operational performance were as presented in table 4.3.

Table 4.3. Findings on Operational Performance.

\begin{tabular}{llllll}
\hline Statements & $\mathbf{N}$ & Min & Max & Mean & Std. Dev \\
\hline $\begin{array}{l}\text { Firm receives inputs in time } \\
\text { Firm makes delivery to }\end{array}$ & 68 & 1 & 5 & 3.34 & .683 \\
$\begin{array}{l}\text { customers in time } \\
\text { Firm has good relationship } \\
\text { with suppliers }\end{array}$ & 68 & 2 & 5 & 3.71 & .624 \\
$\begin{array}{l}\text { Firm has good relationship } \\
\text { with customers }\end{array}$ & 68 & 2 & 5 & 3.53 & .889 \\
$\begin{array}{l}\text { Firm incurs minimum costs } \\
\text { in purchasing }\end{array}$ & 68 & 1 & 5 & 3.34 & .908 \\
$\begin{array}{l}\text { Firm incurs minimum costs } \\
\text { in manufacturing }\end{array}$ & 68 & 1 & 5 & 3.57 & .698 \\
$\begin{array}{l}\text { Firm incurs minimum costs } \\
\text { in distribution }\end{array}$ & 68 & 2 & 5 & 3.24 & .775 \\
$\begin{array}{l}\text { Firm incurs minimum costs } \\
\text { in marketing }\end{array}$ & 68 & 1 & 5 & 3.53 & .743 \\
$\begin{array}{l}\text { Firm incurs minimum costs } \\
\text { in inventory management } \\
\begin{array}{l}\text { My organization incurs } \\
\text { minimum costs in recovery }\end{array}\end{array}$ & 68 & 2 & 5 & 3.12 & .764 \\
\hline
\end{tabular}

\begin{tabular}{|c|c|c|c|c|c|}
\hline Statements & $\mathbf{N}$ & Min & Max & Mean & Std. Dev \\
\hline $\begin{array}{l}\text { Firm incurs minimum costs } \\
\text { in waste management }\end{array}$ & 68 & 1 & 5 & 3.78 & .770 \\
\hline $\begin{array}{l}\text { Firm emits minimum wastes } \\
\text { into the environment }\end{array}$ & 68 & 2 & 5 & 3.68 & .818 \\
\hline $\begin{array}{l}\text { Firm receives minimum } \\
\text { complaints on environmental } \\
\text { management issues }\end{array}$ & 68 & 1 & 5 & 3.74 & .745 \\
\hline $\begin{array}{l}\text { Firm receive minimum } \\
\text { complaints on quality }\end{array}$ & 68 & 1 & 5 & 3.82 & .668 \\
\hline $\begin{array}{l}\text { Firm receives minimum } \\
\text { complaints on government } \\
\text { regulations }\end{array}$ & 68 & 2 & 5 & 3.93 & .798 \\
\hline $\begin{array}{l}\text { Firm uses its current capacity } \\
\text { optimally }\end{array}$ & 68 & 2 & 5 & 3.74 & .683 \\
\hline $\begin{array}{l}\text { Firm achieves maximum } \\
\text { productivity }\end{array}$ & 68 & 2 & 5 & 3.34 & .683 \\
\hline Firm receives inputs in time & 68 & 2 & 5 & 3.81 & .675 \\
\hline Valid N (list wise) & 68 & & & & \\
\hline
\end{tabular}

\subsection{Correlation Results}

The correlation analysis of the study revealed the results presented in table 4.4 .

Table 4.4. Correlation Results.

\begin{tabular}{llllll}
\hline & & Recovery & Reuse & Reprocessing & Organizational Performance \\
\hline \multirow{4}{*}{ Recovery } & Pearson Correlation & 1 & $.247^{*}$ & $.310^{* *}$ & $.381^{* *}$ \\
& Sig. (1-tailed) & & .021 & .005 & .001 \\
\multirow{4}{*}{ Reuse } & $\mathrm{N}$ & 68 & 68 & 68 & 68 \\
& Pearson Correlation & $.247^{*}$ & 1 & $.305^{* *}$ & $.367^{* *}$ \\
\multirow{2}{*}{ Organizational } & Sig. (1-tailed) & .021 & & .006 & .001 \\
Performance & $\mathrm{N}$ & 68 & 68 & 68 & 68 \\
*. Correlation is significant at the 0.05 level (1-tailed). & Pearson Correlation & $.381^{* *}$ & $.367^{* *}$ & $.343^{* *}$ & 1 \\
**. Correlation is significant at the 0.01 level (1-tailed). & & .001 & .001 & .002 & 68 \\
\hline
\end{tabular}

Table 4.4 shows the results of correlation analysis on the relationship between the independent variables (recovery, reuse and reprocessing) and operational performance. The Pearson Correlation indicates the nature and strength of the relationship while significance value indicates the statistical significance of the relationship. Correlational analysis was used to test the three hypotheses of the study.

The Pearson Correlation $=0.247$ reveal that there is weak positive relationship between recovery and operational performance of sisal processing firms in Nakuru County. Significance value of $0.021(<0.05)$ reveal that the relationship between recovery and operational is statistically significant.

The Pearson Correlation $=0.305$ reveal that there is weak positive relationship between reuse and operational performance of sisal processing firms in Nakuru County. The significance value of $0.006 \quad(<0.05)$ reveal that the relationship is statistically significant.

\subsection{Reverse Logistics and Operational Performance}

The combined effect of reuse and recovery on operational performance was as presented in table 4.5.

Table 4.5. Combined Effect of Recovery and Reuse on Operational Performance.

\begin{tabular}{lllll}
\hline Model & R & R Square & Adjusted R Square & $\begin{array}{l}\text { Std. Error of } \\
\text { the Estimate }\end{array}$ \\
\hline 1 & $.504^{\mathrm{a}}$ & .254 & .219 & .652 \\
\hline
\end{tabular}

$\mathrm{R}$ square is extent to which recovery and reuse affect operational performance of sisal processing firms in Nakuru County. $\mathrm{R}$ square $=0.254$ reveals that reverse logistics operations have overall prediction of $25.4 \%$ on operational performance of sisal processing firms in Nakuru County. 
This implies that in overall, reverse logistics positively affects operational performance of sisal processing firms in Nakuru County.

\subsection{Hypothesis Testing}

The t-tests were used to test the research hypothesis in the study. The findings were as presented in table 4.6.

Table 4.6. Table of Coefficients.

\begin{tabular}{lllllll}
\hline & & \multicolumn{2}{l}{$\begin{array}{l}\text { Unstandardized } \\
\text { Coefficients }\end{array}$} & $\begin{array}{l}\text { Standardized } \\
\text { Coefficients }\end{array}$ & T & Sig (p) \\
\cline { 3 - 5 } & $\mathbf{B}$ & Std. Error & Beta & & \\
\hline & (Constant) & 1.410 & .498 & & 2.834 & .001 \\
1 & Recovery & .239 & .105 & .263 & 2.284 & .026 \\
& Reuse & .251 & .118 & .245 & 2.134 & .037 \\
\multicolumn{2}{l}{ a. Dependent Variable: operational performance } & & \\
\hline
\end{tabular}

The first hypothesis was $\mathrm{Ho}_{1}$ : Recovery has no significant effect on operational performance of sisal processing firms in Nakuru County. The $\mathrm{t}=2.284$ and $\mathrm{p}=0.026(<0.05)$ reveal that recovery has significant positive effect operational performance of sisal processing firms in Nakuru County. The first hypothesis is therefore rejected and conclusion made that recovery has significant positive affect on operational performance of sisal processing firms in Nakuru County.

The second hypothesis was $\mathrm{Ho}_{2}$ : Reuse has no significant effect on operational performance of sisal processing firms in Nakuru County. The $\mathrm{t}=2.134$ and $\mathrm{p}=0.037(<0.05)$ reveal that reuse has statistically significant positive effect on operational performance of sisal processing firms in Nakuru County. The second hypothesis was therefore rejected and it is concluded that reuse has significant positive effect on operational performance of sisal processing firms in Nakuru County.

The multiple regression models for the study can be obtained as shown below;

$$
\mathrm{Y}=1.410+0.239 \mathrm{X}_{1}+0.251 \mathrm{X}_{2}
$$

Where; Y - Operational Performance

$\mathrm{X}_{1}$ - Recovery

$\mathrm{X}_{2}$ - Reuse

The following conclusions were made from the study findings; Recovery has significant positive effect on operational performance of sisal processing firms in Nakuru County. Recovery of materials leads to recovery of value that otherwise could have been lost. It reduces costs of materials as well as facilitates sustainable management of wastes.

Reuse positively affects operational performance of sisal processing firms in Nakuru County and the effect is statistically significant. Reused products are more affordable than newly produced materials thereby creating cost advantage to the organization. Reuse minimizes time it takes to acquire materials thereby enhancing efficiency in the processing operations. Similarly, reuse reduces wastes thereby enhancing operational performance.

The researcher recommends that management of sisal processing firms should look at recovery as a strategic method that can be used to achieve improved environmental responsiveness, social responsiveness and environmental management aspects of operational performance which in return can give an organization a competitive advantage. Similarly, management of sisal should formalize adoption of reuse activities and have written down policies, guidelines and regulations on adoption of reuse operations. There is need to involve employees in reverse logistics operations through training, communication and role allocations in as far as reuse practices are concerned.

Further studies should be conducted on the key determinants and drivers of reverse logistics. Similar study should be conducted on the relationship between reverse logistics and social performance of processing/manufacturing organizations. Lastly, further study should be conducted on the role of top management in adoption of reverse logistics practices.

\section{References}

[1] Amemba, S. C., Nyaboke, P. G., Osoro A. and Mburu, N. (2013). Elements of Green Supply Chain Management. European Journal of Business and Management, 5(12)22222839.

[2] Amenta, E. and Ramsey, K. M. (2010).Institutional Theory. Springer Science Business Media.

[3] Chaves and Chicarelli (2006) Reverse logistics and the relation reverse logistics and the relation between industry and retail industry and retail in the after in the after-sale reverse flow management. Third International Conference on Production., Americas' Region 2006.

[4] Doug Spiers P.E. (2010). Effective Operations Performance Management. Strategic Framework for Success.

[5] Dowlatshahi, S. (2010). A cost-benefit analysis for the design and implementation of reverse logistics systems : case studies approach. International Journal of Production Research, 48(5), 1361-1380.

[6] Export Processing Zones Authority (2005).Kenya's Sisal Industry 2005. Export Processing Zones Authority.

[7] Failte Ireland (2013). Operational Standards of Performance. A guide to help you through the four part process of developing new standards and improving existing ones. Failte Ireland.

[8] Fleischmann, M., Beullens P., Ruwaard, B. and Wassenhove (2001).The impact of product recovery on logistics network design. Production and Operations Management, 10(2).

[9] Global Environmental Management Services (2015).Caring for the Environment. Global Environmental Management Services $L L C$.

[10] Green, K.W., Pamela, Z., Meacham J. \& Bhadauria, S. V. (2012). Green Supply Chain Management Practices: Impact on Performance .Supply Chain Management: An International Journal, 17(3)290-305.

[11] Greve, C. and Davis, J. (2010).Recovering Lost Profits by Improving Reverse Logistics. Commissioned by UPS. 
[12] Gungor, A. and Gubta, S. M. (1999).Issues in environmentally conscious manufacturing and product recovery: a survey .Computers \& Industrial Engineering 36, 811-853.

[13] Hazen, B. T., Cegielski, C. and Hanna J. B. (2011). Diffusion of green supply chain management examining perceived quality of green reverse logistics. The International Journal of Logistics Management 22 (3)373-389.

[14] Hazen, T. B., Cegielski, C. and Hanna, J. B. (2001).Diffusion of Green Supply Chain Management Examining Perceived Quality of Green Reverse Logistics.

[15] IBM (2015).Global environmental management system. Retrieved on $23^{\text {rd }}$ January 2015 from: http://www.ibm.com/ibm/environment/ems/

[16] Kothari, C.R., (2013). Research Methodology- Methods and Techniques, New Delhi, Wiley Eastern Limited

[17] Laosirihongthong, T., Adebanjo, D. and Tan, K. C. (2013).Green supply chain management practices and performance. Industrial Management \& Data Systems, 113 (8), 1088- 1109 .

[18] Lindahl, M., Sundin, E. Östlin, J. and Björkman, M. (2002). Concepts and definitions for product recovery: analysis and clarification of the terminology used in academia and industry. Linköping University Electronic Press.

[19] Loer Kevin (2010). Effective Operations Performance Management. Westin.

[20] Mugenda, M.O. and Mugenda, G .A. (2003). Research Methods: Quantitative and Qualitative Approaches. Nairobi: Central Graphics Services.

[21] Mutimos A. E. (2013). Relationship between reverse logistics practices and organizational performance of manufacturing firms in Kenya .University of Nairobi.

[22] Ninlawan, C., Seksan P., Tossapol K., \& Pilada W. (2010).The Implementation of Green Supply Chain Management Practices in Electronics Industry. Proceedings of the International Multi Conference of Engineers and Computer Scientists, 17-19 March 2010 Hong Kong.

[23] Oso W. K. and Onen D. (2011): A General guide to writing research proposals and report. $2^{\text {nd }}$ edition, Kampala: Makerere University.

[24] Pires, N. (2007). Modelopara a logísticareversa dos bens de pós-consumoem um ambiente de cadeia de suprimentos. Florianópolis: UFSC.

[25] Price Water House Coopers (2008). How to realize an agile and efficient reverse chain within the Consumer Electronics Industry. Price Water House Coopers.

[26] Quintão, R. T., Jesus, L. and Siegler, J. (2011).Determinants of Reverse Logistics Execution in the Brazilian supermarket industry. $23^{\text {rd }}$ Annual Confernece, Chicago Illions, USA April, 23, 2012.

[27] Rogers, S. D. and Tibben-Lemboke, D. S. (1998).Going Backwards: Reverse Logistics Trends and Practices. Reverse Logistics Executive Council.

[28] Shumon, Z. H., Zaman, K. A. and Rahman, A. (2011). Prospects of remanufacturing: a Bangladesh perspective. International Journal of Industrial Engineering, 18 (5), 254259.

[29] Suresh, K. and Chandrashekara, S. (2012). Sample size estimation and power analysis for clinical research studies. $J$ Hum Reprod Sci. 2012 Jan-Apr; 5(1): 7-13.

[30] Thierry, M., Salomon, M., Nunen, J. and Wassenhove, L. (1995). Strategic Issues in Product Recovery Management. Califonia Management Review, 37 (2)

[31] Van Wormer, T. (n.d).The Four Keys to Operational Performance. Vista is a logistics cost management consulting company.

[32] Yamane, T. (1967). Statistics: An Introductory Analysis, 2nd Ed., New York: Harper and Row.

[33] Zheng, L. and Zhang, J. (2010). Research on Green Logistics System Based on Circular Economy. Asian Social Science, 6(11), 1911-2025.

[34] Zhu, Q., Sarkis, J., Cordeiro, J.J. and Lai, K. (2008b), Firm level correlates of emergent green supply chain management practices in the Chinese context, Omega - The International Journal of Management Science, Vol. 36No. 4, pp. 577-91. 